\title{
PRELIMINARY STUDY ON DIETARY COMPOSITION, FEEDING ACTIVITY AND FULLNESS INDEX OF Boleophthalmus boddarti IN MEKONG DELTA, VIETNAM
}

\author{
Dinh Minh Quang
}

Can Tho University, dmquang@ctu.edu.vn

\begin{abstract}
The mudskipper Boleophthalmus boddarti (Pallas, 1770) is an important commercial fish, but information on its dietary composition has been limited. This study was carried out from March 2013 to February 2014, in Tran De, Soc Trang, Mekong Delta, Vietnam to understand its food, foraging intensity and fullness index. A total of 120 fish specimens including 63 females $(8-15 \mathrm{~cm}$ in TL) and 57 males $(9.5-15.1 \mathrm{~cm}$ in TL) were collected and analysed. The results showed that the sex ratio of $B$. boddarti was close to $1: 1$ and this mudskipper would be a herbivorous fish due to high relative gut length value $(R G L>1)$ based on 120 gastrointestinal tract length analysis. Among them, 75 fish stomachs were used for food item determination. The $B$. boddarti fed mainly on Bacillariophyta (82.97\%), and detritus was also composed in its stomach contents (13.26\%). The mudskipper showed high in foraging intensity due to high fullness index value. The variation of food composition of this fish depended on season, but not in gender and fish size. The results provided useful information on diet composition of $B$. boddarti and contributed to our knowledge for other gobies living in the monsoonal regions.
\end{abstract}

Keywords: Mudskipper, herbivorous, food items, feeding intensity, fullness index.

\section{INTRODUCTION}

Information on interactions of fish in the aquatic systems is obtained from knowledge on food and feeding habits of fish [6, 13, 18, 23] that provides a key to select suitable fishes for aquaculture [3, 19]. Feeding activity of fish varies with numerous factors such as the amount of precipitation and the availability of food organism composition [19, 23]. Information on stomach contents are associated with the food consumption and assimilation rates of fish $[3,6,13]$.

Moreover, information on diet composition, relative gut length $(R G L)$, fullness index $(F I)$ and foraging intensity are helpful for fish farming $[3,4,13,19]$, that are used to evaluate the variation of environmental factors [7]. The intraspecific variation of fish feeding habit is determined based on the change of $R G L$ values $[2,21]$, and the $F I$ is used as a biological indicator to examine the foraging intensity of fish [8]. Little information, however, is available on food and feeding habits of fishes in the Mekong Delta where fish composition is diversity, especially the gobiids living in the estuary and muddy regions [25].
Although the Boddart's goggle-eyed goby, Boleophthalmus boddarti (Pallas), is a commercial fish [17], its information is limitted to geography distribution [12], burrow morphology and utilization [9, 11], growth pattern [10]. Ravi (2013) [20] reported that this mudskipper in Indian water used diatoms as main food items, but this author dose not examine the variations on its food and feeding habits between gender, fish size and season. Therefore, this study aimed to understand the dietary composition, relative gut length and foraging intensity of immature and mature of male and female $B$. boddarti during the dry and the wet seasons, that will contribute to our knowledge on food and feeding habit of other goby fishes in the monsoonal regions.

\section{MATERIALS AND METHODS}

\section{Study site}

This study was conducted thoughout year in Tran De district, Soc Trang province, Vietnam, from March 2013 to February 2014. Soc Trang comprises a long coastline connected with mangroves and mud flat habitats with semidiurnal tide. Dry (January-May) and wet (June- 
December) are two main seasons with an average annual temperature of $\sim 28^{\circ} \mathrm{C}$ and 400 $\mathrm{mm}$ monthly precipitation in the wet season. Soc Trang is a typical province representing the natural environment in Mekong Delta [22].

\section{Fish collection}

Fish specimens were collected monthly using deep gill nets with $1.5 \mathrm{~cm}$ mesh in the codend, $2.5 \mathrm{~cm}$ mesh in the mouth and $5 \mathrm{~m}$ long. Deep gill nets were set at the highest tide and retrieved after 2-3 hours during ebb tide along the margin of mangrove forest $\left(9^{\circ} 28^{\prime} 47.41 " \mathrm{~N}, \quad 106^{\circ} 12^{\prime} 25.96 " \mathrm{E}\right) . \quad$ Fish specimens collected were preserved in $5 \%$ formalin before transporting to the laboratory. The surface water temperature and salinity at the study site were monthly recorded using a thermometer and a refractometer, respectively, which were used to test the influence of environmental factors on sex ratio.

\section{Relative gut length and feeding habit analysis}

In the laboratory, after being sexed using the shape of the urogenital papilla which was round in females and narrow in males, fish specimens were measured in total length $(T L$, nearest 0.1 $\mathrm{cm})$ and body weight $(W$, nearest $0.01 \mathrm{~g})$. The gastrointestinal tracts were then removed from specimens and measured in length (nearest 0.1 $\mathrm{cm})$ to calculate the relative gut length $(R G L)$ as the ratio of the gut length to the total length, that was used to determine feeding habit of this fish [2]. The variations of $R G L s$ from immature (total length less than $11.52 \mathrm{~cm}$ ) to mature fish (total length from $11.52 \mathrm{~cm}$, unpublished data) were used to conform whether feeding habit of $B$. boddarti changed as fish growth or not based on the method described by Saikia et al. (2012) [21].

\section{Stomach content analysis}

Dietary composition in the stomach of $B$. boddarti was determined using occurrence method in which the number of stomachs containing a particular item of food was expressed as a percentage of the total number of stomach examined [15]. Moreover, the point method was also used to examine the food composition of this fish [16]. According to this method, the stomach contents were stored in 5\% formalin for determination food items, and the contents were dispersed and made up to a known volume with filtered tap water. Using optical and stereoscopic microscopes, food items were identified to the genus level based on the identification description described by Vu \& Duong (2012) [26]. After obtaining point, percentage of each prey was used to compare food composition between gender, season and fish size [27].

\section{Fullness index and foraging intensity}

Stomach content of each $B$. boddarti was removed and weighed to the nearest $0.01 \mathrm{mg}$ to determine the fullness index $(F I)$ using the equation $F I=W_{i}^{*} 10000 / W$, where, $W_{i}$ is weight of stomach and $W$ is fish body weight. The $F I$ then was used to determine the foraging intensity of $B$. boddarti based on the method of Saikia et al. (2012) [21].

\section{Data analysis}

The ratio, male:female, was tested using $\chi^{2}$. The student t-test was used to examine if the $R G L$ of this fish differed from stand value of one, and if $F I$ varied with gender and season based on the method of Saikia et al. (2012) [21]. All test were performed using SPSS v.21 and set at 5\% meaningful level.

\section{RESULTS AND DISCUSSION}

\section{Sex ratio and environmental factors}

A total of 120 fish specimens including 63 females (8-15 cm in TL) and 57 males (9.5-15.1 $\mathrm{cm}$ in TL) were collected. The proportion of male $B$. boddarti was not significantly different from females between the dry and the wet seasons $\left(\chi^{2}=0.3, P>0.05\right)$. Although the water temperature in the dry season $\left(29.07 \pm 1.32^{\circ} \mathrm{C}\right)$ was not significantly different from that in the wet season $\left(28.33 \pm 1.05^{\circ} \mathrm{C}\right.$, t-test, $\mathrm{t}=1.78$, $P>0.05)$, salinity in the study site was higher in the dry season $(8.86 \pm 3.75 \%$ ) compared to that in the wet season $(2.68 \pm 2.28 \%$ o, t-test, $\mathrm{t}=16.67$, $P<0.001)$. The ratio, male:female, of this fish species was roughly $1: 1$, suggesting that the minor variations of temperature and salinity had no affect on its sex ratio. Likewise, the number of male Pseudapocryptes elongatus distributed the same region was not significantly different from females [24], and the sex ratio of 
Apistogramma caeteiare and Oreochromis niloticus is not strongly affected by temperature and salinity change $[1,5]$.

\section{Relative gut length and feeding habit}

The $B$. boddarti would be a herbivorous fish as its relative gut length $(R G L=2.19 \pm 0.35)$ was significantly greater than standard number of one (t-test, $\mathrm{df}=119, \mathrm{t}=37.62, P<0.001)$ based on scale described by Al-Hussaini (1947) [2] and without any zooplankton or any smallaquatic animals presented in stomach contents of the mudskipper. However, Ravi (2013) [20] reported that $B$. boddarti lived in Indian water is omnivorous fish as little percentage of Nematoda, Polychaeta and fish eggs was found in its stomach contents. The contradictory between the present and previous studies indicated that $B$. boddarti may feed randomly these food items.

\section{Dietary composition}

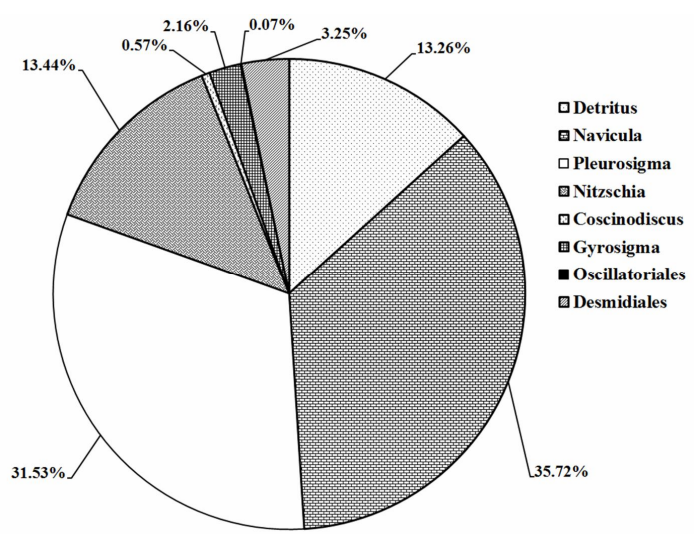

Figure 1. Food composition in the stomach of Boleophthlamus boddarti based on point data

The analysis stomach contents of $75 B$. boddarti specimens (45 females and 30 males) showed that Bacillariophyta $(82.97 \%)$ occupied the highest percentage of point, closely followed by detritus (13.26\%, fig. 1). Moreover, its stomach also contained Charophyta (Desmidiales $=3.25 \%$ ) and Cyanophyta (Oscillatoriales $=0.07 \%$, fig. 1$)$. There were five genera of Bacillariophyta in stomach contents of this goby species including Navicula (35.27\%), Pleurosigma (31.53\%), Nitzschia (13.44\%), Gyrosigma (2.16\%) and Coscinodiscus (0.57\%, fig. 1$)$.
Male and female B. boddarti also fed mainly on Bacillariophyta and detritus, which was found in immature and mature fish during dry and wet seasons as well (table 1). It suggests that Bacillariophyta was mainly composed in the stomach of this fish species, which was similarly to the previous study on this species in Indian water of Ravi (2013) [20]. Both the present and previous studies reported that $B$. boddarti fed on detritus as well. Little percentage of Charophyta, Cyanophyta and Gyrosigma was found in stomach of this gobiid species, indicating that it might already consume these food items. The food composition of this goby varied with seasonal change, but did not change with gender and fish size based on point percentage (table 2). The food composition of $B$. boddarti was similar to $P$. elongatus living in the same habitat with $B$. boddarti $[8,24]$. Although feeding habit of fish is specific-species, the food composition of $B$. boddarti was slightly different from previous study in India, and was similar to P. elongatus in Mekong Delta, seeming that natural environment conditions may influence the food item composition of these gobiid species.

In the present study, the high percentage dissimilarity in food composition of $B$. boddarti was found in season variable. It may be because that the high rainfall in the wet season influenced on phytoplankton community in the study site. Similarly, Hinojosa-Garro et al. (2013) [14] reveals that food items in Belonesox belizanus and Paraneetroplus melanurus were significantly different between rainy and dry season in Mexico as high precipitation in wet season influenced on aquatic organism community in study site.

\section{Fullness index and foraging intensity}

The fullness index (FI) of $B$. boddarti was not significantly different within season and gender (t-test, $\mathrm{df}=73, \mathrm{t}=0.171$ for season and $\mathrm{t}=$ 0.083 for gender, $P>0.05$ ). However, the foraging intensity variation of this fish depended on the seasonal variation as the interaction between gender and season influencing on its $F I$ (ANOVA, $\mathrm{F}=6.47$, $P<0.05$, fig. 2). The high $F I$ value of female $B$. 
boddarti was high in the wet season (i.e., spawning season, unpublished data) compared to that in the dry season. It may be the $B$. boddarti need much energy for reproduction during the spawning period. The FI value of males were higher in the dry compared to that in in the wet season. It seems that males spent more time to take care of their eggs and new generation during spawning season. The high percentage of empty stomach (37.5\%) indicated that $B$. boddarti may be high digestion rate.

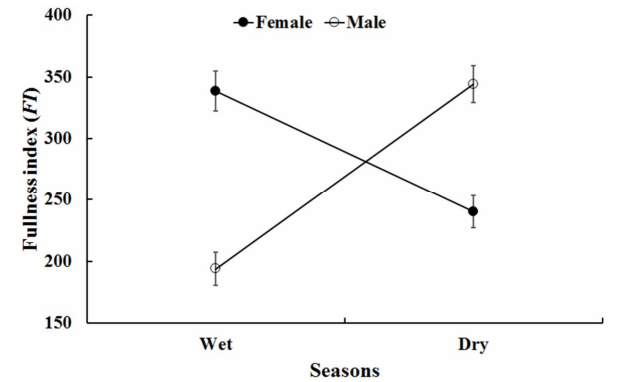

Figure 2. The interaction of season and gender influencing on the variation of fullness index (FI) of Boleophthalmus boddarti (vertical line: standard error)

Table 1. Food composition of Boleophthalmus boddarti based on occurrence $(\mathrm{O})$ and point $(\mathrm{P})$ percentage

\begin{tabular}{|c|c|c|c|c|c|c|c|c|c|c|c|c|c|}
\hline \multirow{2}{*}{\multicolumn{2}{|c|}{ Food items }} & \multicolumn{2}{|c|}{$\begin{array}{l}\text { Female } \\
(\mathrm{n}=45)\end{array}$} & \multicolumn{2}{|c|}{$\begin{array}{l}\text { Male } \\
(\mathrm{n}=30)\end{array}$} & \multicolumn{2}{|c|}{$\begin{array}{c}\text { Imature } \\
(\mathrm{n}=24)\end{array}$} & \multicolumn{2}{|c|}{$\begin{array}{l}\text { Mature } \\
(\mathrm{n}=51)\end{array}$} & \multicolumn{2}{|c|}{$\begin{array}{l}\text { Wet season } \\
\quad(\mathrm{n}=30)\end{array}$} & \multicolumn{2}{|c|}{$\begin{array}{l}\text { Dry season } \\
\quad(n=45)\end{array}$} \\
\hline & & $\begin{array}{c}\mathrm{O} \\
(\%)\end{array}$ & $\begin{array}{l}\mathrm{P} \\
(\%)\end{array}$ & $\begin{array}{c}\mathrm{O} \\
(\%)\end{array}$ & $\begin{array}{l}\mathrm{P} \\
(\%)\end{array}$ & $\begin{array}{c}\mathrm{O} \\
(\%)\end{array}$ & $\begin{array}{l}\mathrm{P} \\
(\%)\end{array}$ & $\begin{array}{c}\mathrm{O} \\
(\%)\end{array}$ & $\begin{array}{l}\mathrm{P} \\
(\%)\end{array}$ & $\begin{array}{c}\mathrm{O} \\
(\%)\end{array}$ & $\begin{array}{l}\mathrm{P} \\
(\%)\end{array}$ & $\begin{array}{c}\mathrm{O} \\
(\%)\end{array}$ & $\begin{array}{c}\mathrm{P} \\
(\%)\end{array}$ \\
\hline & Detritus & 21.03 & 20.27 & 22.73 & 15.41 & 21.26 & 11.28 & 22.07 & 19.46 & 25.00 & 10.43 & 10.43 & 26.53 \\
\hline \multirow{5}{*}{  } & Navicula & 14.68 & 18.07 & 16.53 & 23.32 & 17.32 & 10.77 & 14.99 & 21.79 & 14.42 & 24.63 & 24.63 & 11.11 \\
\hline & Pleurosigma & 16.27 & 31.48 & 17.77 & 23.77 & 16.54 & 41.64 & 17.17 & 26.04 & 14.42 & 15.36 & 15.36 & 44.64 \\
\hline & Nitzschia & 15.08 & 10.37 & 16.12 & 9.57 & 15.75 & 13.90 & 15.53 & 9.48 & 14.91 & 7.27 & 7.27 & 13.22 \\
\hline & Coscinodiscus & 15.08 & 11.10 & 16.53 & 27.54 & 13.39 & 20.62 & 16.62 & 19.25 & 21.16 & 38.00 & 38.00 & 3.05 \\
\hline & Gyrosigma & 6.75 & 0.61 & 7.44 & 0.35 & 11.02 & 1.54 & 5.72 & 0.33 & 4.81 & 0.13 & 0.13 & 1.11 \\
\hline Charophyta & Oscillatoriales & 4.76 & 0.60 & 0.41 & 0.04 & 1.58 & 0.07 & 3.00 & 0.21 & 0.48 & 0.02 & 0.02 & 0.35 \\
\hline Cyanophyta & Desmidiales & 6.35 & 7.48 & 2.48 & 0.00 & 3.15 & 0.18 & 4.90 & 3.44 & 4.81 & 4.16 & 4.16 & 0.77 \\
\hline
\end{tabular}

Table 2. Comparison of the food items (percentage of point) in stomachs of Boleophthlamus boddarti within gender, fish size and season

\begin{tabular}{|c|c|c|c|c|c|c|c|c|c|c|}
\hline \multicolumn{2}{|c|}{ Food items } & $\mathrm{F}$ & M & $\begin{array}{c}\text { Diffe } \\
(\%)\end{array}$ & Immture & Mature & $\begin{array}{c}\text { Diffe } \\
(\%)\end{array}$ & $\begin{array}{c}\text { Dry } \\
\text { season }\end{array}$ & $\begin{array}{c}\text { Wet } \\
\text { season }\end{array}$ & $\begin{array}{r}\text { Diffe } \\
(\%)\end{array}$ \\
\hline \multicolumn{2}{|c|}{ Detritus } & 20.27 & 15.41 & 4.86 & 11.28 & 19.46 & 8.18 & 10.43 & 26.53 & 16.10 \\
\hline \multirow{5}{*}{ 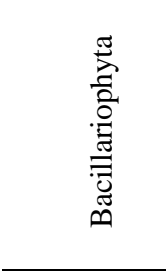 } & Navicula & 18.07 & 23.32 & 5.25 & 10.77 & 21.79 & 11.02 & 24.63 & 11.11 & 13.52 \\
\hline & Pleurosigma & 31.48 & 23.77 & 7.71 & 41.64 & 26.04 & 15.60 & 15.36 & 44.64 & 29.28 \\
\hline & Nitzschia & 10.37 & 9.57 & 0.80 & 13.90 & 9.48 & 4.42 & 7.27 & 13.22 & 5.95 \\
\hline & Coscinodiscus & 11.10 & 27.54 & 16.44 & 20.62 & 19.25 & 1.37 & 38.00 & 3.05 & 34.95 \\
\hline & Gyrosigma & 0.61 & 0.35 & 0.26 & 1.54 & 0.33 & 1.21 & 0.13 & 1.11 & 0.98 \\
\hline Charophyta & Oscillatoriales & 0.60 & 0.04 & 0.56 & 0.07 & 0.21 & 0.14 & 0.02 & 0.35 & 0.33 \\
\hline Cyanophyta & Desmidiales & 7.48 & 0.00 & 7.48 & 0.18 & 3.44 & 3.26 & 4.16 & 0.77 & 3.39 \\
\hline
\end{tabular}

F. Female; M. Male; Diffe. Difference.

\section{CONCLUSION}

B. boddarti was herbivorous fish and fed mainly on Bacillariophyta, and its diet composition variation was influenced by seasonal change. Female $B$. boddarti had more foraging intensity than males in spawning 
season, whereas there was a contradictory in dry season.

Acknowledgments: I am grateful to Mr. Ty (local fishermen) for fish collection and my students (Mr. Huy, Mr. Trong, Ms. Nhu, Ms. Truc and Ms. Giang) for measuring fish length and weight, and to anonymous reviewers for constructive comments.

\section{REFERENCES}

1. Abucay J. S., Mair, G. C., Skibinski, D. O. F., Beardmore, J. A., 1999. Environmental sex determination: the effect of temperature and salinity on sex ratio in Oreochromis niloticus L. Aquaculture, 173(1-4): 219-234.

2. Al-Hussaini A. H., 1947. The feeding habits and the morphology of the alimentary tract of some teleosts living in the neighbourhood of the Marine Biological Station, Ghardaqa, Red Sea. Pub. Mar. Biol. Stat. Ghardaqa (Red Sea), 5: 1-61.

3. Azadi M. A., Nasiruddin, M., Rahman, A. S. M. S., 2009. Food and feeding habits of the clupeid, Gonialosa manmina (Ham.) from the Kaptai Lake, Bangladesh. Chittagong Univ. J. B. Sci., 4(1): 53-61.

4. Bakhoum S., Fatas, S., 2003. Food and feeding habits of Bayad fish Bagrus bajad (Forsskal, 1775) in El-Nozha hydrodrome. Egypt. Aquat. Biol. Fish., 7(3): 197-211.

5. Baroiller J. F., D'Cotta, H., 2001. Environment and sex determination in farmed fish. Comp. Biochem. Physiol. C Toxicol. Pharmacol., 130(4): 399-409.

6. Bayhan B., Sever, T. M., Kara, A., 2013. Diet composition of the Mediterranean horse mackerel, Trachurus mediterraneus (Steindachner, 1868) (Osteichthyes: Carangidae), from the Aegean Sea. Belg. J. Zool., 143(1): 15-22.

7. Bonato K. O., Delariva, R. L., Silva, J. C. D., 2012. Diet and trophic guilds of fish assemblages in two streams with different anthropic impacts in the northwest of Paraná, Brazil. Zoologia (Curitiba), 29(1): 27-38.

8. Bucholtz R. H., Meilvang, A. S., Cedhagen,
T., Christensen, J. T., Macintosh, D. J., 2009. Biological Observations on the Mudskipper Pseudapocryptes elongatus in the Mekong Delta, Vietnam. J. World Aquac. Soc., 40(6): 711-723.

9. Clayton D. A., Vaughan, T. C., 1986. Territorial acquisition in the mudskipper Boleophthalmus boddarti (Teleostei, Gobiidae) on the mudflats of Kuwait. J. Zool., 209(4): 501-519.

10. Dinh M. Q., 2014. A preliminery study on length-weight relationship of the mudskipper Boleophthalmus boddarti in soc trang. J. Biol., 36(1): 88-92.

11. Dinh M. Q., Giang, N. T. T., Duy, N. N. L., Dong, D. H., Hau, L. T., 2014. Burrow configuration and utilization of the bluespotted mudskipper Boleophthalmus boddarti caught in Soc Trang, Vietnam. Kasetsart Univ. Fish. Res. Bull., 38(2): 1-7.

12. Froese R., Pauly, D., 2015. FishBase. www.fishbase.org. Access 24 June 2015.

13. Gumus A., Yilmaz, M., Polat, N., 2002. Relative importance of food items in feeding of Chondrostoma regium Heckel, 1843 , and its relation with the time of annulus formation. Turkish J. Zool., 26(3): 271-278.

14. Hinojosa-Garro D., Arceo-Gomez, J., Zambrano, L., Escalera-Vazquez, L. H., 2013. Fish diet composition in permanent and semi-permanent pools in tropical wetlands of the Yucatan Peninsula. Neotrop. Ichthyol., 11(4): 881-890.

15. Hynes H. B. N., 1950. The food of freshwater sticklebacks (Gasterosteus aculeatus and Pygosteus pungitius), with a review of methods used in studies of the food of fishes. J. Anim. Ecol., 19(1): 36-58.

16. Hyslop E. J., 1980. Stomach contents analysis - a review of methods and their application. J. Fish Biol., 17(4): 411-429.

17. Ip Y. K., Chew, S. F., Lim, L. L., Low, W. P., 1990. The mudskipper. Paper presented at the Essays In Zoology, National University of Singapore, National 
University of Singapore: 83-95.

18. Jhingran A., 1972. Diet-composition of Gudusia chapra (Ham.) from the Ganga river system. Paper presented at the Proceedings of the National Academy of Sciences, India Section B: Biological Sciences, Springer, India: 94-105.

19. Manon M. R., Hossain, M. D., 2013. Food and feeding habit of Cyprinus carpio var. specularis. J. Sci. Found., 9(1-2): 163169.

20. Ravi V., 2013. Food and feeding habits of the mudskipper, Boleophthalmus boddarti (Pallas, 1770) from Pichavaram mangroves, southeast coast of India. Int. J. Mar. Sci., 3(12): 98-104.

21. Saikia A., Abujam, S., Biswas, S., 2012. Food and Feeding habit of Channa punctatus (Bloch) from the Paddy Field of Sivsagar District, Assam. Bull. Env. Pharmacol. Life Sci., 1(5): 10-15.

22. Soc Trang Statistical Office, 2012. Soc Trang after 20 years establishment - a development way. Soc Trang Statistical
Office, Soc Trang (in Vietnamese).

23. Specziár A., Erős, T., 2014. Dietary variability in fishes: the roles of taxonomic, spatial, temporal and ontogenetic factors. Hydrobiologia, 724(1): 109-125.

24. Tran D. D., 2008. Some aspects of biology and population dynamics of the goby Pseudapocryptes elongatus (Cuvier, 1816) in the Mekong Delta (Dissertation), Universiti Malaysia Teregganu, Malaysia.

25. Valbo-Jørgensen J., Coates, D., Hortle, K., 2009. Fish diversity in the Mekong River basin. In: Campbell IC (ed) The Mekong, Academic Press, San Diego, United States pp. 161-196.

26. Vu N. U., Duong, T. H. O., 2012. Zooplankton and phytoplankton. Can Tho University Publishing, Can Tho.

27. Yang K. Y., Lee, S. Y., Williams, G. A., 2003. Selective feeding by the mudskipper (Boleophthalmus pectinirostris) on the microalgal assemblage of a tropical mudflat. Mar Biol., 143(2): 245-256.

\title{
KẾT QUẢ NGHIÊN CÚU BƯớC ĐẦU VỀ PHỔ THỬC ĂN, CƯỜNG ĐỘ BẮT MỒI VÀ HỆ SỐ NO CỦA Boleophthalmus boddarti Ở ĐỒNG BẦNG SÔNG CỦU LONG, VIẸTT NAM
}

\author{
Đinh Minh Quang \\ Trường Đại học Cần Thơ
}

\section{TÓM TÁT}

Boleophthalmus boddarti là một loài cá kinh tế nhưng thông tin về phổ thức ăn của chúng vẫn còn hạn chế. Nghiên cứu này được tiến hành từ tháng 3 năm 2013 đến tháng 2 năm 2014 ở, Trần Đề, Sóc Trăng, Đồng bằng sông Cửu Long, Việt Nam nhằm cung cấp thông tin về phổ thức ăn, cường độ bắt mồi và hệ số no của loài này. Tổng số 120 mẫu cá bống sao bao gồm 63 cá cái $(8-15 \mathrm{~cm})$ và 57 cá đực $(9,5-15,1 \mathrm{~cm})$ thu được và phân tích. Kết quả cho thấy loài cá này thuộc nhóm cá ăn thực vật bởi vì chỉ số sinh trắc của ống tiêu hóa $(R G L>1)$ dựa kết quả phân tích 120 ống tiêu hóa cá. Trong số này, chỉ có 75 ống tiêu hóa của cá có chứa thức ăn và được dùng để xác định phổ thức ăn của loài này. Loài này sử dụng Bacillariophyta $(82,97 \%)$ như là thức ăn chính, ngoài ra 13,26\% của mùn bã hữu cơ cũng được tìm thấy trong ống tiêu hóa của chúng. Loài này có cường độ bắt mồi mạnh do chúng có hệ số no cao. Sự biến động thành thức ăn của loài này phụ thuộc vào mùa vụ nhưng không phụ thuộc vào giới tính và kích cỡ cá. Kết quả của đề tài đã cung cấp thông tin hữu ích về phổ thức ăn của loài này cũng như đã bổ sung những hiểu biết của chúng ta cho những loài cá bống phân bố ở vùng nhiệt đới gió mùa.

Tù khóa: Cá bùn, cá ăn thực vật, phổ thức ăn, cường độ bắt mồi, chỉ số no.

Ngày nhận bài: 15-2-2015 